KOME - An International Journal of Pure Communication Inquiry

Rhetorics of War in the Arts, Volume 5 Issue 2, p. 81-84. (C) The Author(s) 2017 A Century of War (1917-2017). Reprints and Permission: Bucharest, Rhetorics of War in the Arts International Conference kome@komejournal.com

Published by the Hungarian Communication

\title{
Zsuzsanna Kemenesi
}

independent researcher, HUNGARY

\author{
"I wish I had known \\ when beginning \\ ' $A$ ' all that I had learned \\ when I had finished \\ ' $\mathrm{Z}$ '"'
}

Extending the limits of the political effects and diplomatic steps, the war is the final outcome of dialogues and discourses - that failed. Due to the transformation of the state, symbolic wars nationally are followed by international conflicts. The Rhetorics of War in the Arts Conference at the Romanian Academy discussed the visual outcomes and the diversity of interpretations of the attitudes.

Dr. Adrian-Silvan Ionescu is the director of the "G. Oprescu" Institute of Art History of the Romanian Academy and an Associate Professor at the National University of Arts in Bucharest. He received his Ph.D. in the history of Romanian photography and specialized in the history of civil and military costumes of the 19th century of fine arts and urban civilization. Ionescu lectured about the Cartoons in Occupied Bucharest (1917-1918) and the attention to local circumstances and characters. Discussed military events, such as satirizing profiteers, shortages of goods, forced leisure of activities, and even Romanian political characters that brought the country to its knees - at the occupied south of Romanian territories. The satirical drawings were supposed to cheer up the solders that experienced first hand the country that was destroyed by the Central Powers. World War I represents an important landmark in the development of the Romanian satirical drawing.

Adriana Dumitran analyzed two visual discourses that were used during the neutrality years of war between 1914-16. Including political figures of the moment and portraits of the leaders of belligerent armies and war scenes from the military conflict zones, which especially destroyed

\footnotetext{
${ }^{1}$ Pearce-Moses, Richard (2005): A Glossary of Archival and Records Terminology. The Society of American Archivists, Chicago p. 27.
}

Address for Correspondence: Zsuzsanna Kemenesi email: dr.kemenesizsuzsanna[at]gmail.com Article received on the 29th November. Article accepted on the 12th December, 2017.

Conflict of Interest: The author declares no conflict of interests. 
key institutions and monuments. Adriana Dumitran's sensibility is shown by the subject matter that was chosen: the years of neutrality. The texts expressed the control and understatement imposed by military neutrality, and at the same time war was viewed through photographs and illustrations, which aimed and expressed in the press the reality of war through visual forms. Adriana Dumitran is the expert of the Romanian history of photography 1960-1919 and librarian at the National Library of Romania.

According to Ramona Caramelea children's publications maintained the culture of war aiming to sensitize young people to military values. Ramona Caramelea lectured about the Images of War in Romanian Children's Magazines (1939-45) highlighting the shocking fact that military actions during the 20thcentury are not limited to war confrontations. By mobilizing intellectual and material resources aiming to sensitize children to military values throughout stories that were seemingly unrelated to war. The illustrations of children's books and magazines conveyed the message of political iconography and ideology. The images supported the narrative that was supposed to promote the culture of war.

Steve Yates is an expert of history of early modern photography, the first and only Fulbright Scholar who received the prestigious award three times to the USSR, Russia, Ukraine, Lithuania, Latvia, Belarus in 1991, and Russia in 1995 and 2007. Yates's keynote lecture Inventing Modern Photomontage to Guernica: Artistic Actions from World Wars contained a general approach to the aesthetics of war. "War is a catalyst to prototypes of modern innovation and invention in the arts." Yates' lecture embraced the anti-art and nontraditional forms that influenced transdisciplinary directions. Events beginning a century ago in World Wars also meant inventions and innovations in the arts in response, expressing another future with original styles that unfolded throughout the 20th century.

Celina Lunsford's lecture concerned the Fashion Photography Reflecting Crisis and Hope. Louise Dahl-Wolfe and The Harper's Bazaar Years during WWII and the Beginning of Cold War. As America's oldest fashion Magazine, Harper's Bazaar kept working during the crises of the Great Depression leading to World War II. Maintaining this public interest even during the economic crises and boom of the global expansion of American ideologies. Politics and developing world events continually influenced the choice of locations of the photographs. Lunsford gave great insight to the ambivalence of the crises and hopes that ruled common sense during WWII, from her aspects as Artistic Director and experience at the Fotografie Forum Frankfurt.

In his lecture War Trauma and Book Market in Interwar Romania, Bogdan Popa, a researcher of the "N. Iorga" Institute of History of the Romanian Academy, investigated the effects of exploring writing of the novel and publishing activities during WWI. Resulting in the diversity of military, political and social events during the war. This was still limited to war memorials and overshadowed by the Great War. Giving the opportunity to the small, yet growing public that read about the unprecedented and individual trauma, giving the obvious need to humans.

Musicologist at the "G. Oprescu" Institute of Art History of the Romanian Academy, Marian Lupaşcu, studies the Romanian, Armenian and Gypsy musical traditions that are connected to war and soldiering topics. The research focused on the rural folk music, rites and ceremonials, genres, repertoires, as well as the area of theoretical interest. Furthermore research includes the topic of methodology of musical structure like rhythm, pitch, architectonic systems and transcription, maintaining their cultural and ethnic identity in a foreign and, most of the time, in an unsympathetic environment. 
Carmen Popa spoke about the Deeply Impacting Echoes of the Two World Wars in Romanian Music. The ethical and aesthetic survey involves the most impressive moments of Romanian history. Lofty sounds about the Romanian spirit, as they always fought defensively, wisely, safeguarding wholeheartedly their land, for their nation with faith, with bright minds and big hearts, even as a mixed choir and small orchestra.

Literary quality and historical truth presented by Romanian writers investigate both the personal and collective war experience. Yet this was rather limited to war memorials and overshadowed by the Great War. Giving the obvious need to a small, yet growing public that read about an unprecedented collective and individual trauma.

According to Virginia Barbu a strong personality of the interwar Romanian art was Ion Theodorescu-Sion (1882-1932). One of the exponents of the "national-style" in painting, remarkable for a sharp and clear outline and at the same time its sobriety of physiognomes. Elena-Christina Brăgea lectured about the fact that when Romania was in its active neutrality period, the diplomatic, military and social preparations were "made in order to enter the war in convenient conditions." The neutrality and dynamics of the military actions were about to increase the sympathy towards the Allies and pushed forward all Romanians to a political unity and a feeling of a homogeneous country. Furnica included cartoons, verses, maxims, thoughts, and epigrams that were signed by Francis Sirato and some other talented cartoonists.

1. Illustration: Front cover design: A heavy gun, Fortepan Archive. Ciprian Ciuclea

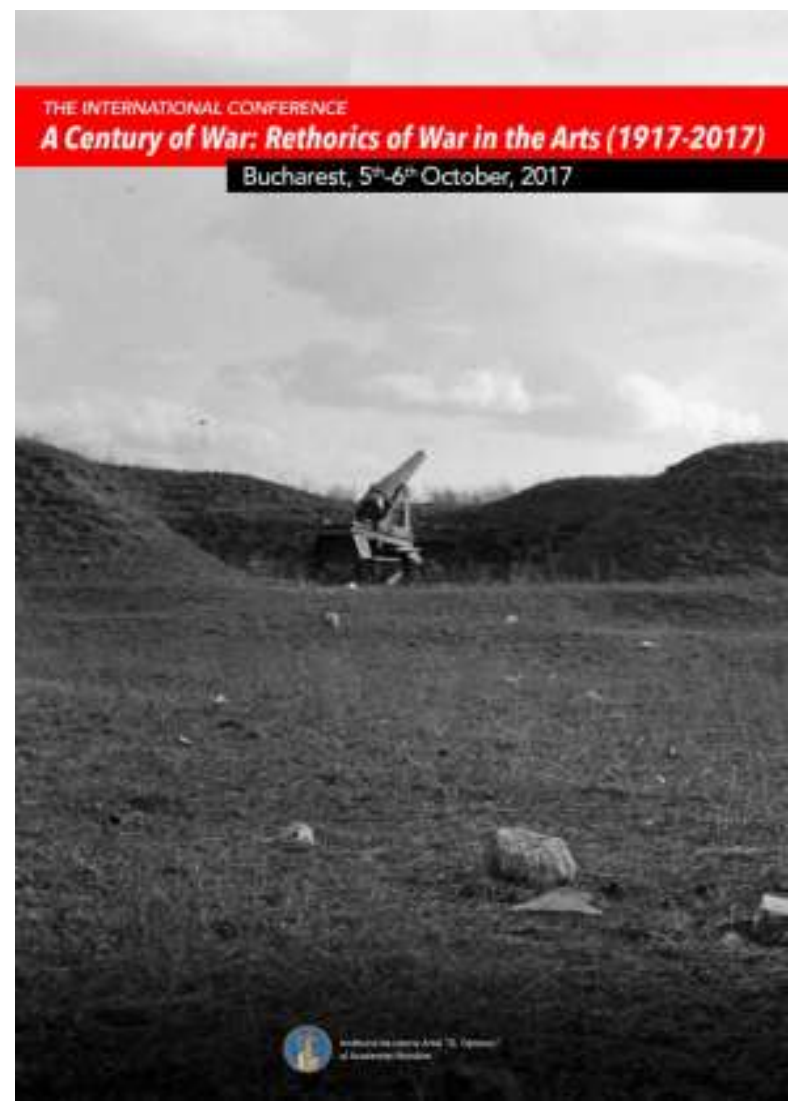

The images of belligerent countries, the atmosphere of daily life in different places, were shaping the ideas of war. Last but not least, Elena-Christina Brăgea analyzed the relationship 
between the public and the magazine in order to identify the interdependencies between them - it's a territory of wisdom. Elena-Christina Brăgea approaches the field by the history of political science, pursuing Ph.D. studies at L'École Doctorale francophone en Sciences Sociales.

After 1945 the society was brainwashed, mostly by party propaganda patterns. Idealizing their interests, erasing some entire chapters of the recent past, and wishing to control better the present. However with this intention there was no trust any more in the newly installed power. According to the statement by Manuela Cernat for filmmakers were not allowed to speak all over the country about the unpleasant side of life. Quite a convincing thesis. There is a lot to learn from Manuela Cernat who served as a jury member for over 200 national and international film festivals such as Cannes, Berlin, Venice, San Sebastian, Bergamo, Valladolid, Bilbao, New Delhi and other cities globally.

The anti-war artists presented by Andrea Domesle dealt with the present. The Basel based theorist focused on relevant socio-political themes, highlighting differences between national narratives about the war and the cultures commemorating it. Part of the approach is to distinguish the private memory and the collective memory.

Petter Österland's lecture "In the Eyes of the War: A Collection of First World War Stereo Photos" included some after-battle pictures, and certainly the 'corps of the unknown' before they entered the great slaughter. "Less horror, less dead, less misery" was the intellectual aspect to the war. Men that, through the fine excellence and quality of the photographs, came so close in time and vision.

The years of neutrality of European war was also presented. Adrian Dumitran said "two visual discourses were used during the neutrality years with which the public was already accustomed: portraits of the leaders of the belligerent armies, political figures of the moment, and war scenes from all the military conflict zones, destroyed cities and monuments." Inaugurating the chemical weapons, tank battles and involving aerial bombardments, the victims discreetly disappeared, But some of the stories, especially the stories of the enemies, were passed on to their children and grandchildren. Overall the characteristics of the dominators were the same all over the world, not counting on the effects of their own children. From the rich photographic material left behind after conflicts, by those who made the details of war as documents, we can actually read the destiny of their entire family. Bogdan-Gheorghe Iorga lectured from an aspect that the Great War was the first war that was mapped by the photography.

There is an extended amount of images that reflected the impacts on life of a certain community. Silvana Rachieru Assistant Professor at the Faculty of History, University of Bucharest is an expert of the Romanian-Ottoman Relations between 1878-1908. After nine years experience in cultural diplomacy and receiving her Ph.D. in the History considered, she is an acknowledged expert on social and diplomatic history of the Ottoman Empire and Romanian-Ottoman relations during the 19th century.

At the Romanian Academy speakers including historians, art historians and artists summarized an entire situation in one glance. The "Rhetoric of War in the Arts" Conference dealt with real events with plausible narrations and unpublished contributions. 